\title{
The Recent Work of Chun-chieh Huang, the Second President of the Society
}

Professor Chun-chieh Huang 黄俊傑 served for nine years as the Dean of the Institute for Advanced Studies in Humanities and Social Sciences of National Taiwan University (hereafter NTU). In January 2017, he retired from NTU after teaching there for nearly a half century. On the day of his retirement, the University contracted him as a Distinguished Chair Professor. In his postretirement, Professor Huang continues his life mission of teaching and academic research work at Wen-de Academy, established for him by a dear friend.

The founder and director-in-chief of Wen-de Academy is Zhu Maonan (朱茂男), who warmly invited Professor Chun-chieh Huang to serve as the Academy Dean. Mr. Zhu Maonan is a thirtieth generation descendent of the Song Neo-Confucian master, Zhu Xi. For many years, Mr. Zhu has promoted and supported research on Zhu Xi's learning. Professor Huang suggested naming the academy "Wen-de," which signifies "culture and virtue." Since 2017, many academic activities have been held at Wen-de, including "International Conference on the History of

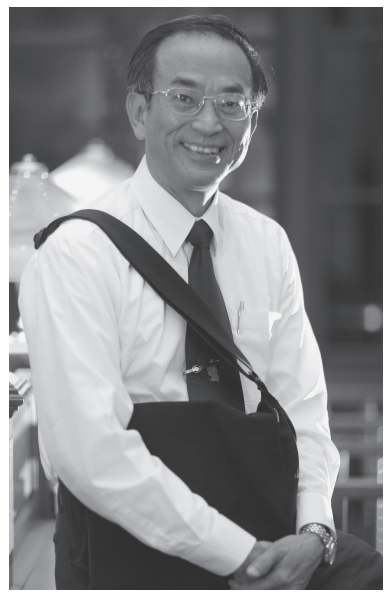
Intellectual Exchange in East Asia" (2019; cohosted by the Institute for Advanced Research of Nagoya University), "Symposium on General Education" (2018), "Roundtable Forum of Domestic Liberal Arts College Deans" (2017), and other activities. Professor Huang receives a continuous stream of renowned visiting scholars from around the world. Domestic university professors and students fill chartered buses from all around Taiwan to attend Professor Huang's lectures at Wen-de Academy. Additionally, Wen-de Academy cohosts a series of Confucian Entrepreneur Forums with the Taiwan Association of Confucian Entrepreneur Culture. Invited speakers have included Dr. Sun Chen, former president of NTU; Dr. Liu Chao-shiuan, former Premier of the Republic of China (Taiwan); Dr. Lee Si-chen, former president of NTU; and Professor Tao Demin of Kansai University, to deliver lectures in the Confucian Entrepreneur Forum series.

Over the past quarter of century, Professor Huang has been promoting the study of "East Asian Confucianisms" from a transcultural perspective. After 
Professor Huang retired from NTU, many of his books continue to be translated and published in foreign languages. In the last two years, several of his books appeared in Japanese, including Shisoshi no kanten kara mita Higashi Ajia (Tokyo: Fukyosha, 2018) translated by Fujii Michiaki (藤井倫明訳《思想 史的観点からみた東アジア》東京: 風響社, 2018年), and Jukyo to Kakumei no aida: Higashi Ajia ni okeru Jo Fuku-kan (Fukuoka: Shukosha, 2018) by Ogata Yasushi (緒形康譯:《儒教と革命の間一東アジアにおける徐復観》)(福岡: 集広舎, 2018年). As to English, Diana Arghirescu translated his Xu Fuguan in the Context of East Asian Confucianisms (Honolulu: University of Hawai'i Press, 2019). Many of Professor Huang's books were also translated into French, German, Slovenian, Spanish, Korean, and Vietnamese, signifying his farreaching international academic influence.

As to instruction, the sound of Professor Huang's lectures fill the classroom without cease. On the day of his retirement from NTU, he announced his wish to be a volunteer for NTU, politely declining to be paid for any future teaching in appreciation to his beloved alma mater. After retirement, he designed and offered several new university level general education classes, including "Inquiry into Confucius and Mencius" and "Confucianism and Buddhism in Comparison." For the general public, he offered a classics seminar on "Confucianism and Buddhism: Mutual Comprehension."

For his scholarly achievements of several decades, Professor Huang mounted another peak of academic recognition in August 2019 when he had the honor of being named "Member of Academia Europaea." Academia Europaea was first proposed in 1985 by the British Royal Society, a venerable organization with a four-hundred-year history. National scientific academies in other European countries immediately rose up in support, and Academia Europaea was formally established in 1988. The Academy embraces every field of the natural sciences, the humanities, and the social sciences, and is a truly world class academic organization. The Academy has posted Professor Chun-chieh Huang's webpage.

URL https://www.ae-info.org/ae/Member/Huang_Chun-Chieh

(Prepared by De-min Tao; translated by Kirill Thompson, worked with Dr. Huang as Associate Dean of the Institute for Advanced Studies in Humanities and Social Sciences of NTU) 